\title{
Sosialisasi Memerangi Berita Hoaks Kepada Siswa SMA Kartika VIII-1 Jakarta
}

\author{
Agus Salim 1 , Djudjur Luciana Radjagukguk², Masnah ${ }^{3}$ \\ 1,2,3Fakultas Ilmu Sosial Dan Ilmu Politik Universitas Nasional \\ email: 1agussalim.unas21@gmail.com, 2djudjurluciana01@gmail.com, \\ 3masnahfadholi@gmail.com
}

\begin{abstract}
Abstrak
Banyaknya informasi yang salah tetapi terlihat begitu meyakinkan kebenarnya, hal demikian dapat terjadi karena banyak informasi yang bias sehingga diperlukan nalar kritis kita dalam memilih informasi yang diterima, mana informasi yang sesuai fakta dan mana informasi yang bias. Pengabdian kepada masyarakat dilakukan di SMA VIII- 1 Kartika dengan tujuan memberikan pemahaman dalam menyeleksi informasi yang diterima para remaja dan upaya menimbulkan nalar kritis terhadap berita-berita yang dibaca oleh para remaja, Pengabdian kepada masyarakat ini menggunakan metode diskusi dengan pemberian materi lalu para siswa melakukan tanya jawab setelah itu diakhiri dengan menganalisa berita-berita yang tersebar di internet dan memilah dari berita tersebut mana yang berita hoaks dan mana yang termasuk dalam berita benar. Sehingga hasil dari pengabdian kepada masyarakat ini memberikan wawasan dan pegetahuan baru kepada para remaja dalam mengindentifikasi informasi yang beredar di internet serta membangkitkan daya berfikir kritis para remaja terhadap berita yang diterima di branda-beranda media sosial mereka.
\end{abstract}

Kata Kunci: Informasi Digital, Berita Hoaks, Remaja

\begin{abstract}
There is a lot of false information that appears to be true since a lot of information is biased, thus we need critical reasoning to determine which information is accurate and which information is false. At Kartika VIII- 1 High School, community service is carried out with the goal of providing understanding in selecting information acquired by teenagers and an endeavor to produce critical reasoning on the news that they read. This community service uses the discussion technique by supplying material to the students, who then discuss it. After then, the question and answer session was followed by an analysis of the news that had been distributed on the internet, with the goal of determining which stories were hoaxes and which were actual news. So that the outcomes of this community service bring fresh insights and knowledge to teens in recognizing information circulating on the internet and reawakening their critical thinking power in response to news they receive on their social media sites.
\end{abstract}

Keywords: Digital Informations, Hoaxes, Teenager 


\section{Pendahuluan}

Berdasarkan data Survei Masyarakat Telematika Indonesia (MASTEL) Tahun 2019 menemukan banyaknya hoaks yang diterima masyarakat, 93,20 \%, yaitu hoaks tentang isu sosial politik. Berdasarkan temuan Kominfo bahwa ditemukan 1.401 Sebaran Isu Hoaks terkait Covid-19, dijelaskan bahwa Kementerian Komunikasi dan Informatika melibatkan penyelenggara platform digital untuk mencegah penyebaran hoaks virus Korona. Hingga 5 Mei 2020 hasil pantauan Tim AIS Ditjen Aptika, menunjukkan 1.401 konten hoaks dan disinformasi Covid-19 beredar di masyarakat (Yusuf, 2020). Sementara penyebarluasan dan pemerataan informasi mutlak harus dilakukan sehingga kehadiran media massa yaitu media cetak, elektronik atau media sosial sangat berperan penting dan harus berlandaskan nilai-nilai etika serta moral dalam memenuhi "right to know" dan right to express". Perkembangan teknologi yang semakin canggih dalam memberikan informasi melalui jaringan yaitu internet, terbukti mampu mempermudah aktivitas manusia dalam berbagai hal. Begitu juga bagi remaja terutama siswa siswi SMA yang sering membaca berita melalui gadget tanpa menyaring kebenarannya. Menurut Sutanta (2009) perkembangan internet merupakan sebuah fenomena dalam dunia komunikasi, di mana media baru membawa banyak perubahan, tidak saja dalam perangkat penyebaran pesan, tetapi juga perubahan di masyarakat. Berkaitan dengan perubahan perangkat peredaran pesan, munculah fasilitas baru seperti blog, e-mail, chatting, serta media sosial seperti facebook dan twitter (Nurudin, 2018). Kemunculan teknologi internet secara otomatis turut pula memengaruhi perkembangan penggunaan media sosial di masyarakat. Salah satuya penyebaran berita yang belum tentu kebenarannya. Pemilihan SMA VIII- 1 Kartika Jakarta Selatan sebagai tempat untuk melaksanakan pengabdian kepada masyarakat mengenai sosialisasi bahaya informasi hoaks karena SMA VIII- 1 Kartika merupakan SMA dengan Akreditasi A dan memiliki siswa dengan prestasi yang baik di bidang olahraga, seperti yang dikutip dari smakartika81.sch.id prestasi yang diraih siswa SMA Kartia VIII- 1 yaitu, tahun 2018 juara 3 Bulutangkis Tunggal Putra, juara 3 Karateka Putri jenjang pendidikan SUDIN Wilayah 1 serta Juara 3 Futsal Putra SMABI CUP.

Pengabdian kepada masyarakat ini dilakukan secara daring menggunakan aplikasi zoom yang menjadi keunikan dari pengabdian sebelumnya yang biasa dilakukan bertatap muka langsung, namun pengabdian kali ini dilakukan secara jarak jauh, sehingga dalam pelaksanaanya diperlukan upaya yang cukup efektif agar penyampaian materi dan sosialisasi diterima dengan baik oleh para siswa siswi. Tentu saja dibutuhkan literasi terhadap siswa siswi di SMA VIII- 1 Kartika Jakarta Selatan mengenai berita hoax melalui perkembangan media baru memungkinkan berita atau informasi palsu dapat mudah masuk dan kurang sosialisasi terhadap bahaya hoaks. Para pelajar harus menyadari untuk mengenali ciri-ciri berita hoaks, bahwa berita yang sekiranya menarik maka akan langsung tersebar melalui grup-grup media sosial seperti facebook ataupun whatsapp. Misalnya, dimasa pandemi covid-19, banyak kegiatan yang dilakukan di rumah serta mendapatkan informasi sangat bergantung pada media online. Tentunya rentan sekali terjadinya penyebaran berita yang 
bermuatan hoaks. Sehingga dapat ditarik kesimpulan bahwa berita hoaks semakin banyak mengingat peristiwa luar biasa seperti covid-19 dimanfaatkan oleh segelintir orang untuk mendapat keuntungan dengan menyebar berita-berita hoaks yang dapat menimbulkan persepsi yang salah dan meresahkan di tengah masyarakat yang sedang dilanda ketakutan terhadap dampak dari covid-19. Bahkan informasi dan berita hoaks banyak dikonsumsi oleh kalangan remaja sehingga para remaja dengan mudah terpengaruh dari berita hoaks tersebut, salahsatu pengaruh berita hoaks membuat remaja merasa aman dan meremehkan kondisi saat ini dimana virus covid-19 telah menjangkiti sebagian besar masyarakat dunia. Remaja merupakan pengguna aktif media sosial yang cukup besar, bahkan berdasarkan hasil survey kominfo setidaknya 30 juta anak-anak dan remaja di Indonesia merupakan pengguna internet, dan media digital saat ini menjadi pilihan utama saluran komunikasi yang mereka gunakan. Berdasarkan data tersebut, pengabdian kepada masyarakat ini lebih difokuskan kepada remaja dalam menyosialisasikan mengenai bahaya hoaks.

Sehingga remaja harus semakin mampu memiliah berita yang dibaca, (Baran, 2002) menyatakan bahwa ada 5 kriteria mendasar dalam melek media yaitu: a) Terdapat kesaran terhadap pengaruh dari media. Media bisa merubah dunia yang bersumber dari konten yang diberikan kepada masyarakat. Jika diabaikan pengaruh dari media, maka akan terbawa ke pada perubahan yang dikonstruksi oleh media. b) Terdapat pemahaman terkait komunikasi massa. Jika kita menyadari adanya unsur-unsur dari proses komunikasi massa dan bagaimana mereka berhubungan satu sama lain sehingga kita dapat menciptakan ekspektasi mengenai bagaimana media dapat melayani kita. c) Terdapat upaya untuk menganalisis dan menjadi bahan diskusi pesan media. Dalam mengkonsumsi pesan media dibutuhkan dasar yang menjadi landasan pemikiran dan refleksi. d) Mengetahui terkait isi media sebagai teks yang memberikan pengetahuan mengenai budaya dan kehidupan kita. Berkaitan dengan bagaimana kita mengetahui tentang manusia, sikap, norma yang diperoleh melalui komunikasi. Dalam budaya saat ini pesan media semakin menguasai komunikasi, menciptakan pemahaman dan pengetahuan budaya. e) Kesanggupan untuk merasakan, mengerti dan menghargai isi media.

Tujuan pelaksanaan pengabdian mengenai sosialisasi bahaya akan berita hoaks diharapkan para generasi muda khususnya pelajar SMA Kartika VIII-1 dapat berpikir kritis dalam menerima informasi yang beredar di media sosial dan diharapkan para remaja juga menjadi melek media dengan memberikan kontrol terhadap penafsiran peran media. Pesan yang disampaikan oleh media kebanyakan bersifat bias, sehingga memerlukan filter untuk mencegah kesalahan dalam penafsiran. Sebagai suatu kemampuan, literasi media atau melek media dapat dimiliki oleh semua orang dan dapat dikembangkan. Namun untuk mampu mencapai analisis pesan, dibutuhkan tingkat kematangan emosional dan intelektual. Perlunya dilakukan sosialisasi bahaya dari berita hoaks karena sudah banyak kasus-kasus tindak kejahatan yang dilakukan karena beredarnya berita yang tidak dapat dipertangungjawabkan kebenarannya. Apalagi banyak kasus kejahatan yang dilakukan para remaja karena termakan akan berita hoaks tanpa dikaji terlebih dahulu kebenarannya. Kelompok pelajar SMA yang 
rata-rata berusia 19 - 20 tahun merupakan masa transisi menjadi pemuda dewasa. Kelompok ini termasuk yang rentan dalam membaca berita yang mereka cenderung lebih mudah untuk men-share berita atau info yang mereka terima.

\section{Metode}

Kegiatan pengabdian kepada masyarakat dengan tema "Sosialisasi Memerangi Hoaks Kepada Siswa SMA Kartika VIII-1 Jakarta" menggunakan metode diskusi yaitu metode pembelajaran berbentuk tukar menukar informasi, pendapat dan unsur-unsur pengalaman secara teratur dengan maksud untuk mendapat pengertian yang sama, lebih jelas dan lebih teliti tentang sesuatu atau untuk mempersiapkan dan merampungkan keputusan bersama, melalui aplikasi zoom, karena saat ini sedang mengalami masa pandemic covid 19. Pada sosialisasi yang dilakukan Tim Universitas Nasional membagi kegiatan pada tiga tahap yaitu 1) Memberikan materi dalam bentuk PPT; 2) mengadakan tanya jawab; dan 3) Menganalisis berita hoaks.

Kegiatan pelatihan ini sasaran adalah siswa/i Sekolah Menengah Atas (SMA) Kartika VIII-1 Jakarta Selatan. Menurut (Ramadhan et al., 2018), Pembelajaran elektronik atau disebut dengan istilah e-learning (electronic learning) merupakan salah satu hasil perpaduan antara pemanfaatan teknologi dengan pembelajaran. Perpaduan ini tentunya dimaksudkan untuk meningkatkan kualitas pembelajaran itu sendiri. Pembelajaran yang dikemas dalam bentuk e-learning memungkinkan konten pembelajaran dapat diakses dengan cepat dan tidak terbatas oleh jarak dan waktu melalui penggunaan teknologi internet. Kemudahan akses belajar melalui internet dalam e-learning ini dapat menjadi potensi dalam penyediaan pembelajaran yang dapat diakses banyak pihak.

Begitu juga (Surjono, 2010) berpendapat bahwa pembelajaran hybrid learning atau blended learning merupakan pembelajaran yang mengkombinasi semua bentuk pembelajaran misalnya online, live, maupun tatap muka (konvensional). Selanjutnya (Bibi \& Jati, 2015) menjelaskan blended learning (hybrid learning) secara sederhana dapat didefinisikan sebagai perpaduan metode belajar tatap muka (di dalam kelas) dengan materi yang diberikan secara online.

Pada pelaksanaan kegiatan beberapa tahapan dilakukan, yaitu memberikan pre test, lalu pemberian materi yaitu dengan memberikan penjelasan selama 15 menit agar siswa memahami mengenai "berita hoaks". Tahap berikutnya melakukan tanya jawab, untuk menguatkan pemahaman para siswa mengenai berita hoaks, kemudian Siswa diminta untuk menganalisi berita hoaks pada media sosial. Tahap terakhir pemberian post test. Tim PKM pun memberikan reward kepada siswa yang mampu menganalisis dengan baik mengenai berita hoaks. Pelatihan ini dilakukan Rabu tanggal 16 September 2020.

\section{Hasil dan Pembahasan}

Pengabdian kepada masyarakat yang dilakukan oleh para dosen Ilmu Komunikasi Universitas Nasional terdiri dari Dra. Masnah, M.Si, Djudjur Luciana, M.Si serta Agus 
Salim, M.I.Kom berupaya memberikan informasi dan edukasi agar para remaja tidak mudah tehasut berita hoaks, dan dapat megindentifikasi berita yang diterima apakah hoaks atau tidak. Kegiatan pengabdian kepada masyarakat yang bertema Sosialisasi Memerangi Berita Hoaks ini ditujukan kepada remaja khususnya SMA Kartika VIII-1 Jakarta Selatan. Karena remaja merupakan pengguna aktif dalam bermedia sosial. Pembekalan materi serta latihan dalam memilah berita hoaks yang dilakukan dalam pengabdian kepada masyarakat ini, memberikan hasil kepada para remaja dalam memilah berita benar dan berita bohong dengan cara mengindentifikasi setiap berita yang dibaca.

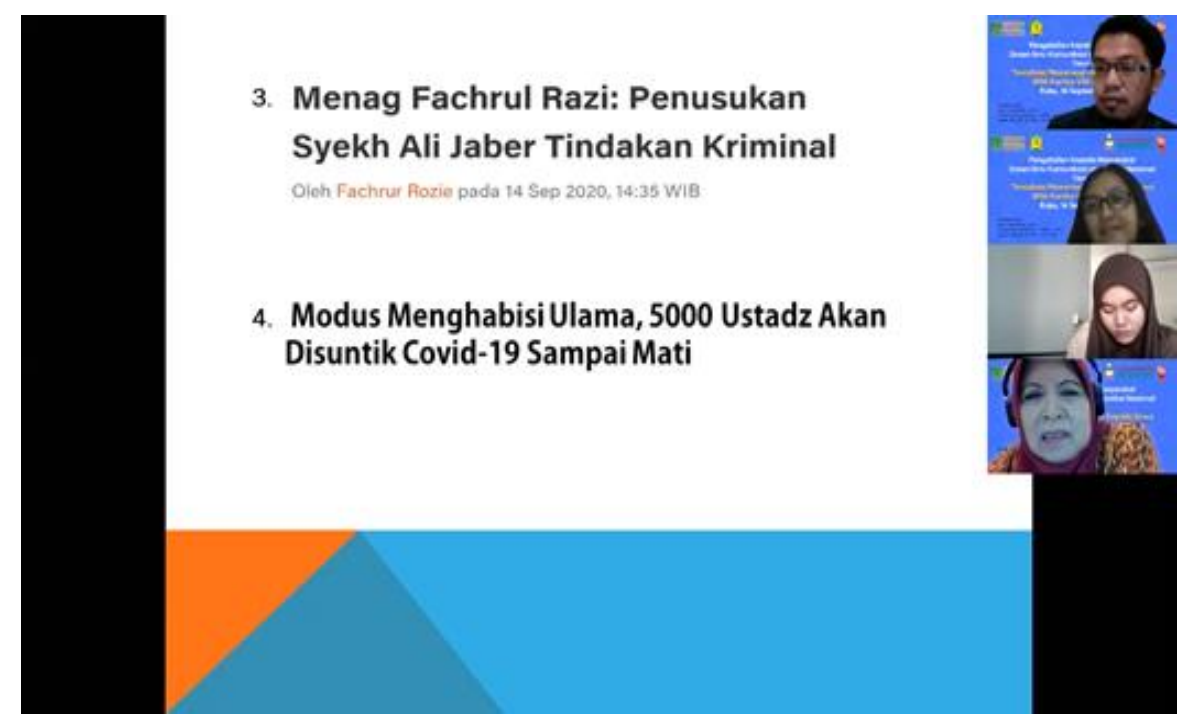

Gambar 1. Analisa berita-berita yang beredar di internet

Kegiatan analisa berita-berita yang beredar di internet ditanggapai antusias oleh para siswa, tampilan-tampilan berita di slide ditujukan ke para siswa-siswi untuk memilah mana berita bohong dan mana berita benar. Terdapat 2 headline berita pada tiap-tiap slide dan para siswa-siswi diminta untuk menganalisa masing-masing berita dengan ciri-ciri berita hoaks yang sudah disampaikan sebelumnya, kemampuan dalam menganalisa berita hoaks yang dilakukan oleh para siswa-siswi merupakan sebuah wujud dari keberhasilan kegiatan pengabdian kepada masyarakat khususnya para remaja SMA karena sesuai dengan tujuan diadakannya pengabdian kepada masyarakat ini adalah untuk membangun daya nalar kritis remaja dalam menerima informasi di media sosial ataupun portal-portal berita online yang terkadang mampir di akun media sosial para remaja, seperti yang di kemukakan oleh (Mulawarman \& Nurfitri, 2017) bahwa dunia dalam jangkauan internet menghilangkan batasan (borderless) nyaris tidak ada rahasia lagi yang bisa ditutupi. 


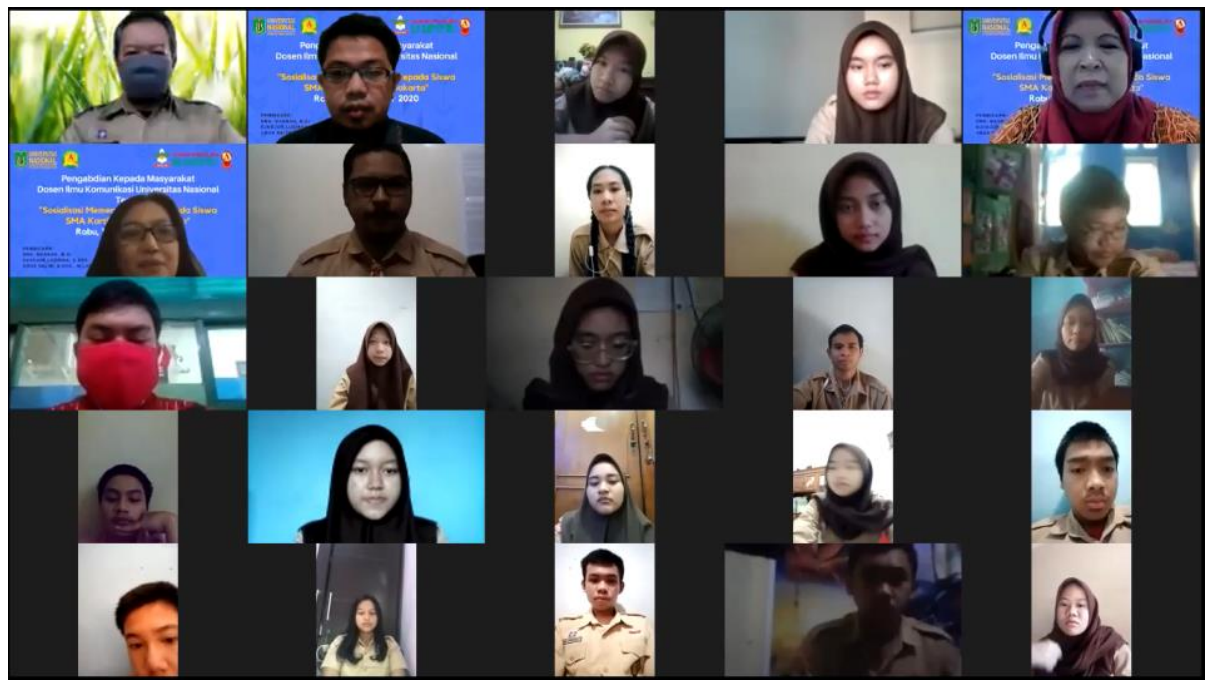

Gambar 2. Para peserta dan pelaksana Pengabdian serta Guru-guru pendamping dari sekolah

Penelitian serupa juga pernah dilakukan (Priambodo, 2019) dengan judul: Surgensi Literasi Media Sosial dalam Menangkal Ancaman Berita Hoax di Kalangan Remaja. Hasil temuan menyatakan bahwa audiens yaitu kalangan remaja di wilayah Kelurahan Balearjosari Kecamatan Blimbing Kota Malang memiliki kemampuan berupa pengenalan media, terutama efek positif dan negatif yang potensial diberikan oleh media. Penelitian yang sama juga dilakukan oleh (Abdillah \& Prasetyono, 2019) menyatakan bahwa peran guru sebagai individu terdekat para siswa saat berada disekolah memiliki peranan penting dalam penaggulangan informasi hoaks yang diterima para remaja, motivasi dari guru meningkat, dalam hal ini dilaksanakan secara intensif dan berkelanjutan, maka kompetensi afektif siswa dalam meminimalisir berita hoaks akan meningkat. Sebaliknya, apabila motivasi guru menurun, dalam hal ini jarang atau bahkan tidak dilaksanakan, maka kompetensi afektif siswa dalam meminimalisir berita hoaks akan mengalami penurunan. Bertolak dari hasil temuan sebelumnya, penulis setuju dengan penemuan kajian sebelumnya bahwa remaja memiliki kemampuan mengenali media dan memahami efek negatif dan efek positif dari media tersebut, dalam hal ini media internet serta pentingnya peran guru sebagai individu terdekat siswa di sekolah untuk memotivasi dalam menyeleksi saat menerima informasi hoaks selain para siswa juga sudah memiliki pengetahuan untuk mengindentifikasi berita bohong dan berita benar. Mengingat internet telah menjadi bagian dari kehidupan setiap orang, dan hampir semua orang memiliki akun di media sosial (Nasrullah, 2015) mengemukakan bahwa hadirnya media sosial dan semakin pesatnya jumlah pengguna internet dari hari ke hari memberikan fakta menarik betapa kekuatan internet begitu besar bagi kehidupan. Untuk itulah perlunya diadakan literasi mengenai bahaya berita hoaks agar remaja memiliki daya kritis dalam memilah dan meyeleksi berita yang dikonsumsi oleh para remaja. 


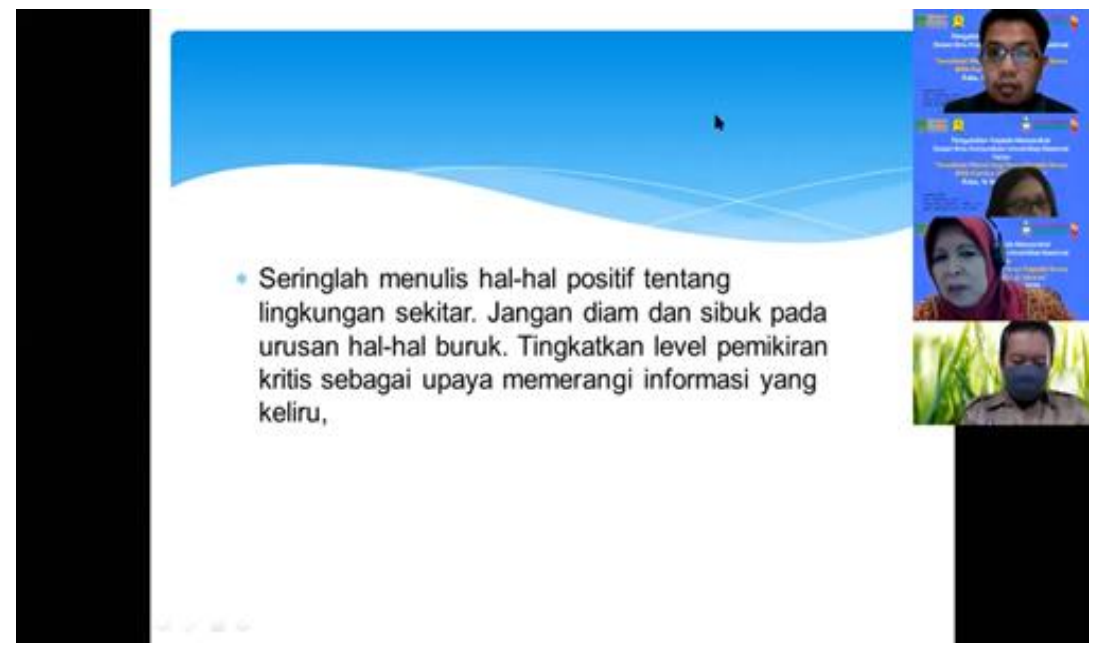

Gambar 3 Pemberian Materi Memerangi hoaks yang beredar di media social

Pengabdian kepada masyarakat yang dilakukan secara daring melalui aplikasi zoom ini diikuti para peserta siswa dan siswi SMA Kartika VIII-1 yang duduk dikelas XI IPS serta didampingi oleh wali kelas yaitu Bapak M. Hatta Sumardi, SE. Sosialisasi memerangi berita hoaks ini sekaligus dijadikan pengisi matapelajaran Pendidikan Kewarganegaraan (PKn) dan guru PKn pun ikut menyertai dalam pengabdian ini yaitu Bapak Chun Cun Tri Kuncoro, S.Pd. Remaja khususnya para siswa-siswi yang masih duduk di bangku Sekolah Menengah Atas merupakan usia yang paling rentan terpapar berita-berita hoaks karena emosi yang belum stabil dan mudah terpengaruh dan terpancing oleh berita-berita yang beredar di internet khususnya di media sosial. Setiap remaja saat ini sudah dipastikan memiliki beberapa akun di media sosial mulai dari Facebook, tweeter, instagram hingga youtube. Dari chanel-chanel tersebutlah berita dapat mengalir deras ke akun masing-masing remaja mulai dari berita benar hingga berita yang bersifat disinformasi atau hoaks. Sehingga penting adanya literasi dengan menyosialisasikan bahaya berita hoaks dan para remaja telah memiliki pengetahuan dalam menyaring informasi bohong dan informasi benar.

Hasil temuan dari kegiatan pengabdian kepada masyarakat ini mengungkapkan bahwa begitu derasnya arus informasi yang diterima oleh para remaja, sehingga sulit bagi para remaja yang dapat membedakan antara informasi benar dan informasi bohong, dengan adanya kegiatan menganalisa berita bohong yang beredar. Menyosialisasikan bahaya yang dapat ditimbulkan dari berita hoaks disampaikan dengan melalui aplikasi zoom meeting dan para siswa yang didampingi para guru sangat antusias menyimak materi serta pelatihan menganalisa berita yang beredar secara online. Kegiatan pengabdian kepada masyarakat ini berajalan sesuai dengan yang diharapkan yakni dengan memberi materi untuk menjelaskan tentang bahaya dari berita hoaks serta ditunjang dengan pelatihan dalam menganalisa berita-berita yang beredar secara online dengan cara melihat dari headline berita, mana yang merupakan berita hoaks dan mana yang berita benar. Kegiatan tersebut disambut positif oleh para guru dan para siswa. 


\section{Simpulan dan Rekomendasi}

Pengabdian kepada masyarakat merupakan sebuah bentuk tanggung jawab kami sebagai dosen yang tidak hanya mengajar dan meneiliti namun juga membantu pemerintah dalam melakukan litersi dan serta sosialisai terhadap masyarakat yang kali ini kami lakukan untuk para remaja agar memiliki pemikiran kritis dalam menerima informasi yang berkunung ke akun media sosial para remaja khususnya siswa siswi SMA Kartika VIII-1 Jakarta Selatan.

Tidak terbendungnya berita-berita hoaks yang beredar di internet maka perlu ada upaya pencegahan agar berita yang masuk ke berada media sosial para remaja dapat dicerna dengan baik, sehingga dalam pengabdian kepada masyarakat yang bertujuan menyosialisaikan bahaya berita hoaks dengan metode yang tidak hanya memberikan materi, namun juga para remaja dilatih untuk ikut serta mengindentifikasi mana berita hoaks dan mana berita benar, dalam sesi analisa berita yang beredar di internet para remaja diminta untuk dapat memilah contoh-contoh berita yang ditampilkan dalam slide. Analisa berita hoaks ini dipandu oleh para dosen yaitu Djudjur Luciana, M.Si dan Agus Salim, M.I.Kom.

Diharapkan kegiatan untuk sosialisasi kepada remaja mengenai bahaya berita hoaks dapat terus berlanjut, karena usia remaja merupakan usia dimana keingitahuan dan mencoba sesuatu yang baru begitu besar, sehingga peran aktif orangtua, guru dan tokoh masyarakat dapat memberikan batasan-batasan dan membentengi para remaja saat mengkonsumsi berita-berita yang beredar di media sosial.

\section{Daftar Pustaka}

Abdillah, A., \& Prasetyono, H. (2019). Pengaruh Reinforcement Guru Terhadap Kompetensi Afektif Siswa Sma Jakarta Timur Dalam Meminimalisir Berita Hoax. Research and Development Journal of Education, 5(1), 3-10.

Baran, J. S. (2002). Introducing to Mass Communication: Media Literacy and Culture: Mc. Graww Hil Companies Boston.

Bibi, S., \& Jati, H. (2015). Efektivitas model blended learning terhadap motivasi dan tingkat pemahaman mahasiswa mata kuliah algoritma dan pemrograman. Jurnal Pendidikan Vokasi, 5(1), 74-87.

Mulawarman, M., \& Nurfitri, A. D. (2017). Perilaku pengguna media sosial beserta implikasinya ditinjau dari perspektif psikologi sosial terapan. Buletin Psikologi, 25(1), 36-44.

Nasrullah, R. (2015). Media sosial: Perspektif komunikasi, budaya, dan sosioteknologi. Bandung: Simbiosa Rekatama Media, 2016, 2017.

Nurudin, N. (2018). Media Sosial Baru dan Munculnya Braggadocian Behavior di 
Masyarakat. Komuniti: Jurnal Komunikasi Dan Teknologi Informasi, 10(1), 25-36.

Priambodo, G. A. (2019). Urgensi Literasi Media Sosial Dalam Menangkal Ancaman Berita Hoax Di Kalangan Remaja Kelurahan Balearjosari Kecamatan Blimbing Kota Malang. Jurnal Civic Hukum, 4(2), 130-137.

Ramadhan, R., Chaeruman, U. A., \& Kustandi, C. (2018). Pengembangan Pembelajaran Bauran (Blended Learning) di Universitas Negeri Jakarta. Jurnal Pembelajaran Inovatif, 1(1), 37-48.

Surjono, H. D. (2010). Membangun course e-learning berbasis moodle. Universitas Negeri Yogyakarta.

Yusuf. (2020). Kominfo Temukan 1.401 Sebaran Isu Hoaks Terkait Covid-19. Aptika.Kominfo.Go.Id/2020/05/Kominfo-Temukan-1-401-Sebaran-Isu-Hoaks-TerkaitCovid-19/. 